\title{
An Empirical Study of Shifting Cultivation in Kombo Jinyo Village under West Siang Region of Arunachal Pradesh
}

\author{
Margum Ado ${ }^{1}$, Marpi Bagra ${ }^{2}$ \\ ${ }^{1} \mathrm{Ph} . \mathrm{D},{ }^{2}$ M.A, B.ED \\ Rajiv Gandhi University, Rono Hills, Doimukh, Arunachal Pradesh, India
}

\begin{abstract}
Jhum cultivation or shifting/swidden cultivation is prevalent since ancient time. It plays an important role for providing livelihood and food security to many people in hilly areas where the other opportunity of cultivation is not feasible. For Jhumias (Jhum cultivators) the importance of shifting cultivation goes beyond mere economic concerns. Jhum crops are adjusted to local condition and chemical for pests/diseases control is not required. Traditionally, Jhumias specially belong to hilly region are totally dependent on Jhum cultivation because Jhum fields are source for many food and non-food crops which helps farmer to maintain their livelihood. Earlier Jhum was only for subsistence purpose, even in present era the output from Jhum is extremely limited and various programmes \& policies implemented by Government is unsatisfactory, but Jhumias are sustaining its livelihood by changing its cropping pattern and land use management. Shifting cultivation is connected to local and regional commodity where cultivator are increasingly integrated to cash crops that are traded locally, regionally which provide resources to themselves and to the society. In the current era deforestation is a challenging one and Jhum cultivation is prevalent in study area. But we cannot incriminate such practice as a sole responsible for deforestation.
\end{abstract}

Key words: Jhum/Shifting/swidden cultivation, Jhumias, Kombo Jinyo, Transition, Cash crop and deforestation.

\section{INTRODUCTION}

The term shifting cultivation or Jhum cultivation is often used interchangeably with slash-and-burn or swidden agriculture. The shifting cultivation is widespread since from ancient time and is being carried out by traditional society even today. Shifting cultivation plays an important role for providing livelihood and food security to many people. For these communities, the importance of shifting cultivation goes beyond mere economic concerns. It is the pivot around which annual work and ritual cycles revolve and involved in part of their life which closely tied to their cultural identity.

The Himalayan region of North Eastern region of India is comprised of eight states namely Assam, Arunachal Pradesh, Manipur, Meghalaya, Mizoram, Nagaland, Sikkim and Tripura. It occupies about seven per cent of total land area and four per cent of total population of the country. About fifty-seven per cent of the geographical area of the region is covered by forests, which are mostly under private or community ownership. Agriculture is the prime source of livelihood for the majority (85\%) of rural population in these regions.

Wangpan, T. and Tangjang, S. (2012) observed that 'Jhum Kheti' or shifting cultivation is the predominant farming system practiced by hilly communities of North eastern region of India, This farming system plays an important role in providing subsistence livelihoods to at least 300-500 million people, which is intricately linked to socio-cultural, ecological and economic aspects of the tribal communities in the hilly region.

According to the $70^{\text {th }}$ round National Sample Survey (NSS) about 63.5 percent of agricultural household are mainly dependent on shifting cultivation which yielded principal source of income and 22 percent of were reported as wage employment for their source of income. Among the major state of the country which 
engaged in shifting agricultural activities (for about 80 percent) were Assam, Chattisgarh and Telangana. Further as per the National Sample Survey (NSS) report, out of per 1000 households Mizoram reported 715 households engaged under Jhum cultivation followed by Nagaland (501 households), Arunachal Pradesh (488 households). Among 29 States and 7 union territories, North Eastern Region of India reported the highest number of households engaged under Jhum cultivation followed by the states like Bihar, Jharkhand and Odisha. Finally out of 36 (states plus union territories), 12 have recorded zero households was engaged in Jhum cultivation which means the absence of practicing Jhum cultivation in that region.

Jhum crops are adjusted to local condition and chemical for pests/diseases control is not required. Traditionally Jhumia households specially belong to hilly region are totally dependent on Jhum because Jhum fields are source for many food and non-food crops, species, medicinal etc, which helps farmer to earn their livelihood.

Quite many scholars have dealt about the case of transforming swidden/ shifting cultivation, these transformations basically dealt with changing cropping pattern for its growing market demand, for generating cash from its output and also dealt with transformation from subsistence/ traditional cultivation to cash cropping and its land use pattern.

To chronologically site a study of Burmon, A. K ; 1977, Poffenberger, M ;1983, Thrupp et al. ;1997, Gaskins, S ;2003, Kerkhoff and Sharma ;2006, have dealt about the transition from subsistence swidden cultivation to cash crop cultivation and its benefits, multiple crop farming due its market demand. They also have a similar study on shifting cultivation as a main source of livelihood for Jhumias.

Also, the study made by Singh, G. B; 1988, International Mountain Society; 2006, Casero et al; 2009, Patel et al; 2013, Sustainable Mountain Development Summit; 2015, dealt with household dependent on Jhum cultivation for consumption and cash generation. Their study also dealt with land use management, government policies to upgrade farming, participation of croppers in limited cultivable hilly terrains.
The above literature surveys have dealt with the transition that taking place under Jhum cultivation. Earlier the Jhum was only for subsistence purpose due to its limited output, even now a day the output from Jhum is limited/merely but Jhumias are sustaining its livelihood by changing its cropping pattern and land use management. However, the deforestation is also a major concern now a day, the study will focus not only in transition, cash cropping, earning, livelihood etc but also try to validate whether the Jhum cultivation is a major cause for deforestation or not in the study area. Therefore the present study aims to attained following objectives.

\section{OBJECTIVES OF THE STUDY}

1. To find the reason behind the persistence of Jhum cultivation.

2. To analysis the transition under Jhum cultivation.

3. To investigate, whether shifting cultivation is cause for deforestation or not.

\section{RESEARCH METHODOLOGY:}

The study will be experiential in nature. The study will take help from both primary and secondary sources. Secondary source will be collected from the published and unpublished sources of Government, Semi Government and Private companies. And Primary data will be collected through framed questionnaire.

\section{SAMPLE SIZE:}

In order to understand the existing conditions of Jhumia households, the data has been collected on the basis of purposive sampling which include structured questionnaire. The study was made on to 25 households out of 43 total households from Jinyo block under Kombo Tarsu Mobuk of west siang district where both male and female were the respondent belongs to Jhumia households.

\section{PROFILE OF THE STUDY AREA:}

The study area Jinyo is one of the blocks of Kombo Tarsu Mobuk village which is situated under West Siang district of Arunachal Pradesh. The village is 15 $\mathrm{km}$ away from district headquarter. There are three blocks in Kombo Tarsu Mobuk comprises of Kon, Mobuk and Jinyo. Kombo Tarsu Mobuk with the total population of 1105 as per census 2011 is the most populous village under west siang district and out of that total population 601 are male and 504 are female. Out of the total population in kombo Tarsu Mobuk 86.16 percent were engaged in work activities like 
employment, earning etc for more than 6 months and remaining 13.84 percent of population were engaged in marginal livelihood providing activities for less than 6 months. There are total 159 households in kombo tarsu mobuk (Kon, Mobuk, and Jinyo) and out of that 43 household belongs to the study area Jinyo. The block Jinyo having the population of 370 and out of that 191 are male and 179 are female.

\title{
VI. DATA ANALYSIS AND INTERPRETATION:
}

\section{What are the Agricultural seasons in the area?}

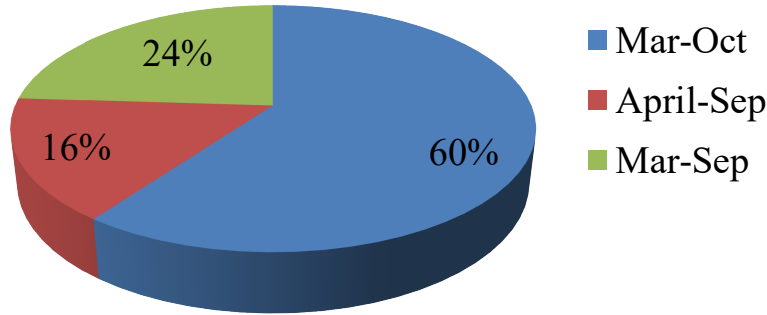

Interpretation: Out of the 25 household in study area 60 percent of respondent means 15 household accepted that the agriculture season starts from March and continue till October last. Remaining $6(24 \%)$ and $4(16 \%)$ household in the village has maintained that the agricultural season starts from March, April to September month.

\section{What are the importance/advantages of Jhum cultivation in your region?}

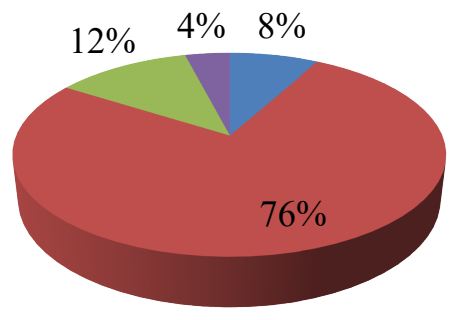

\author{
It is associated with some culture/ Tradition etc \\ - Main sources for firewood, food/Vegetable. \\ Main sources for income generation \\ Other (specify)
}

Interpretation: According to our survey the importance of Jhum/swidden cultivation in their locality 76 percent of respondent replied that it is the main source of firewood, food and vegetable for their daily needs. 12, 8 and 4 percent of respondent replied that the importance of Jhum as income generation and some of them have claimed about cultural/traditional attachment and others respectively.

\section{Under Jhum Cultivation for how many years you continue to grow crops?}

\begin{tabular}{|l|l|}
\hline Growing crops (In Years) & Fallow period (In Years) \\
\hline 2-3 Years & above 10 Years \\
\hline
\end{tabular}

Interpretation: In the study area, the minimum period for cultivation is 2 year and 3 year is the maximum period for Jhum cultivation. 3 year for cultivation is totally depending upon the fertility of the soil. As per survey, the fellow period in survey area is not less than 10 years.

\section{After years of cultivation, what would you do with your Jhum land? (Specify)}

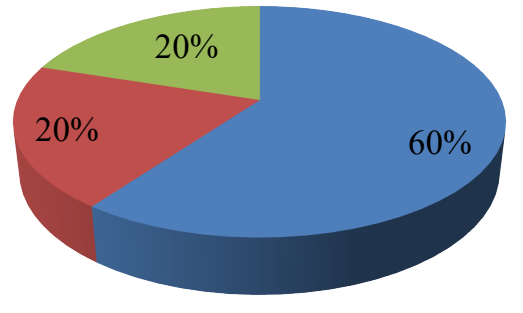

- Left forest to Re-Grow

Just left the field without doing anything

Transform it into orchard like

घother 
Interpretation: As per the survey 60 percent of respondent replied that after 2-3 years of cultivation they left their Jhum land to regrow forest under extensive cares. 20 percent of respondent just left their field without doing anything and another 20 percent of respondent had transformed their Jhum field as an orchard farm like banana, pine apple etc

\section{What are the main causes that you are still practicing Jhum cultivation?}

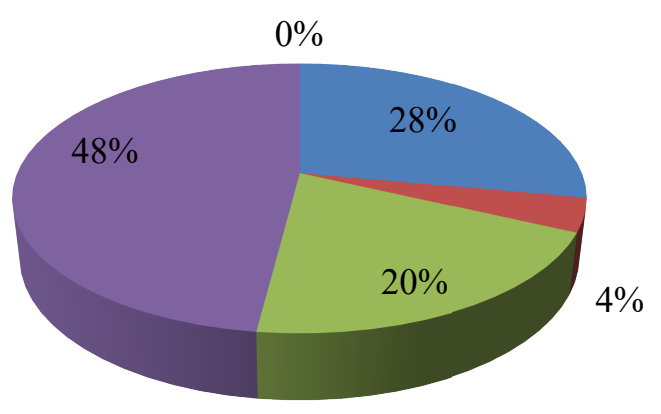

- Don't possessed land for permanent/terrace cultivation

No proper channel/source for irrigation

No other options for cultivation

Better Source for food and Vegetable

- Other (please specify)

Interpretation: Even now a day's Jhum cultivation still continues in many parts of the state and study area also. 48 percent of respondent have claimed that they find Jhum as a better source for food and vegetable for their daily needs. 28 percent of respondent have maintained that due to hilly terrain and no land available/possessed for permanent cultivation they were compelled to continue Jhum cultivation. Remaining 20 percent and 4 percent have claimed that due to no other option for cultivation and lack of proper channel or source for irrigation is the reason that they still continue/dependent on Jhum cultivation.

\section{Which of the following cultivation mode you found most suitable/ benefit this day?}

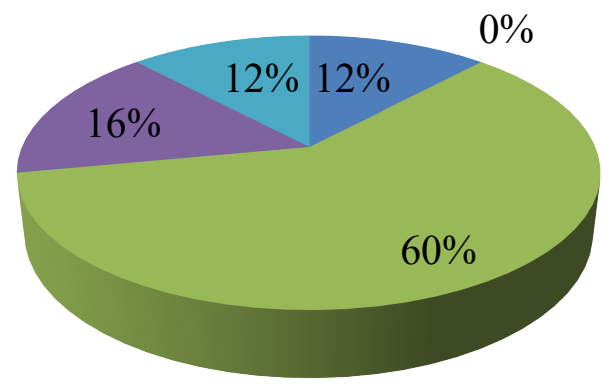

- Shifting cultivation

- Agro Forestry

- Cash crop farming

- Permanent/Terrace cultivation

- Plantation and fruit product specialisation

Interpretation: 60 percent of household found cash crop farming is most beneficial now a day's because by doing this they also consumed and sell their product in market. 16 percent of respondent have claimed permanent/terrace cultivation most suitable and 12 percent of respondent believe that shifting cultivation is suitable for their household. Finally the 12 percent of respondent have asserted that due to changing market price for fruits and other specialization, plantation and specialization for fruits is beneficial for them. However no respondent have chosen for agro forestry may be due to availability of huge forest resources or lack of knowledge.

\section{As per your view which of the listed reasons reduces the forest cover area most?}

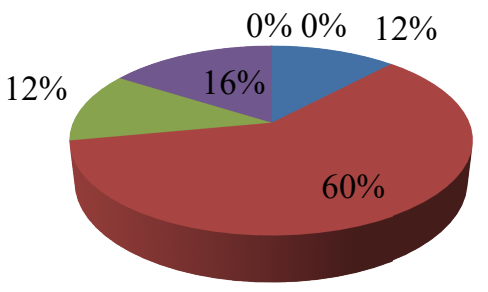

- Shifting cultivation/ slash and burn cultivation

- Commercial Logging / Fire wood Business

- Free grazing/ community use

- Road construction

- Industrial setup

Lack of knowledge on environment 
Interpretation: According to our survey 60 percent respondent has claimed that logging for commercial purpose and firewood business is the major cause for deforestation. 16 percent claimed due to day by day increasing kachha or self created road for commercialization of forest product in jungle is the main cause for deforestation. Finally the cause for deforestation is also associated with no restriction for community use and industrial set up was claimed by respondent.

\section{Have you ever avail any kind of government support during cultivation?}

Yes/ No, if yes please specify.

\begin{tabular}{|c|c|c|}
\hline Response & Yes & No \\
\hline Household & 0 & 25 \\
\hline
\end{tabular}

Interpretation: 25 household in study area have claimed that they did not receive any kind of government support/subsidies for cultivation.

9. What is the Amount $(\mathrm{Kg})$ of rice that you required for your household in a month?

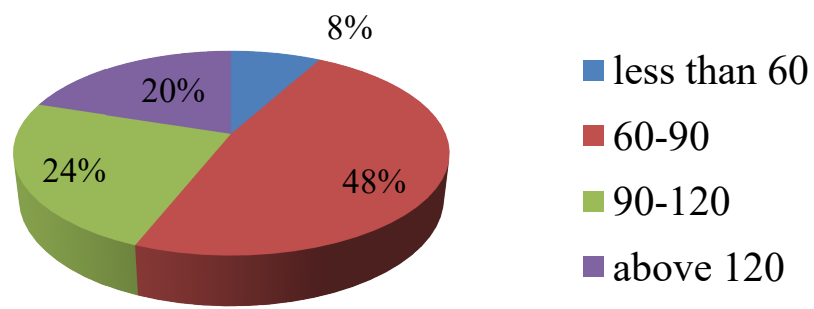

Interpretation: 60 to $90 \mathrm{~kg}$ of rice in a month required for each household was claimed by 48 percent of respondent. 24 percent of household have claimed they require 90 to $120 \mathrm{~kg}$ of rice per month. 20 percent of household require more than $120 \mathrm{~kg}$ of rice/ month. And 8 percent of household require less than $60 \mathrm{~kg}$ of rice in a month.

10. What are the main sources of rice for your household?

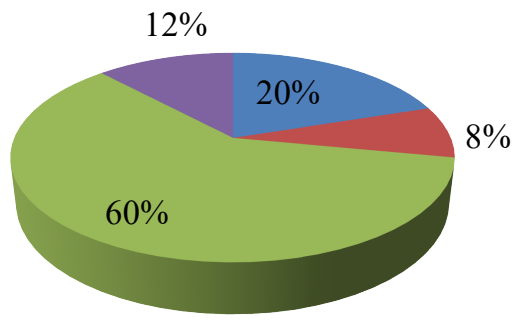
Government
- Shifting Cultivation/ Jhum Cultivation
Terrace/ Permanent cultivation
Open Market (Purchase from market)

Interpretation: Based on the monthly requirement of rice for each household and due to low productivity of rice under Jhum cultivation, 60 percent respondent have laid claim permanent/terrace as their main source of rice. 20 percent respondent maintained government as a sole provider of rice for their household. 12 percent household found market as a main source for rice and remaining 8 percent of household totally dependent on Jhum for their monthly requirement of rice.

11. In your locality do you found any kind of transformation that occurs in traditional Jhum cultivation? Yes/ No. if yes please specify.

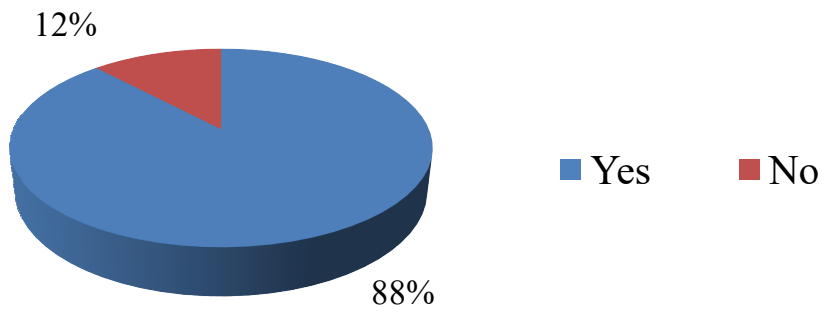




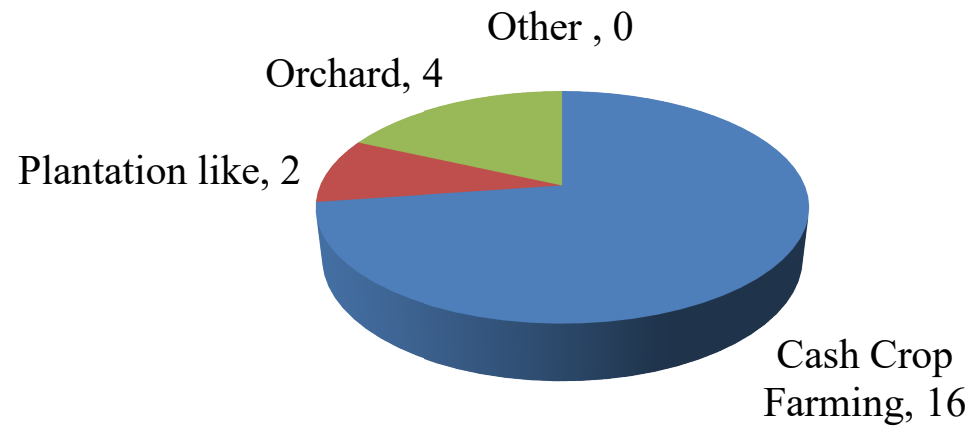

Interpretation: Regarding the transformation that household faced in their locality, 22 respondents has witnessed the transformation that occurred under Jhum cultivation and remaining 3 respondents had not face any transformation. Out of 22 household, 16 respondents faced the transformation like cash crop farming, 4 respondents found transition of Jhum as Orchard farming and 2 respondents replied that they witnessed the transition like teak woods, cardamom, bamboo etc.

12. Do you think that market demand and the agricultural transformation are correlated? Yes/ No, please specify
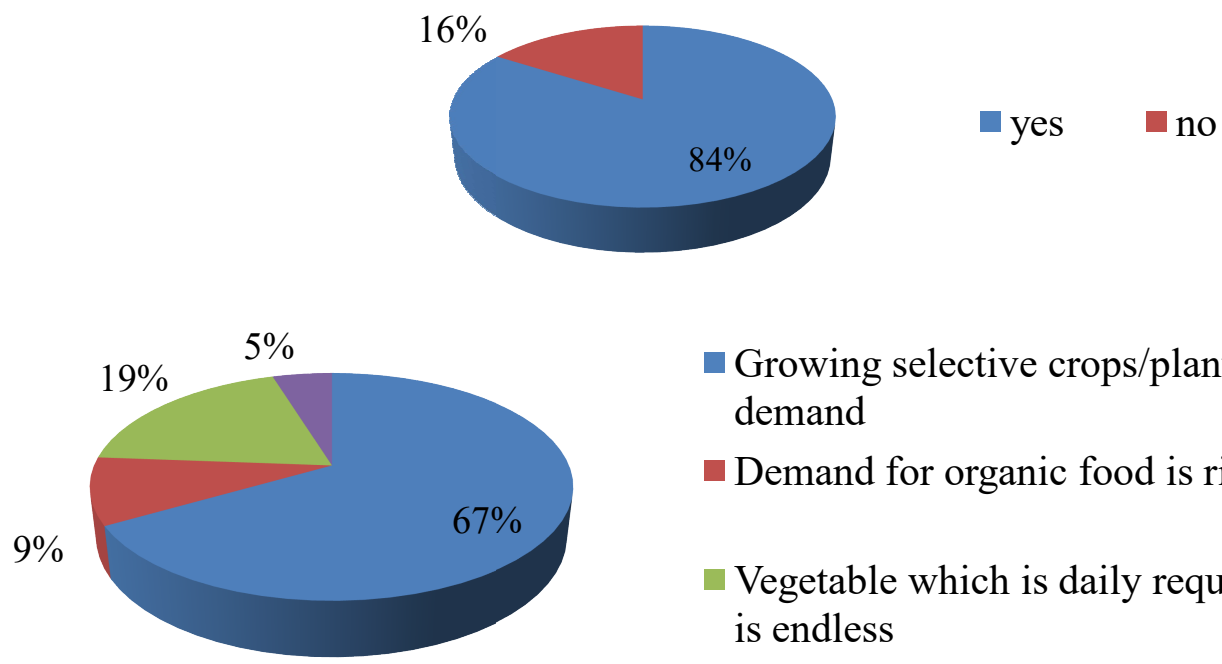

Growing selective crops/plants which are high market demand

Demand for organic food is rising

Vegetable which is daily required item and its demand is endless

- Orchard like

Interpretation: In order to find out the inter-relation between market demand and agricultural transformation, out of $25(100 \%)$ respondents $21(84 \%)$ respondents believe in positive correlation between market and Agri transition and $4(16 \%)$ respondents found no any linkages between market and transition under Agriculture. Within this 21 respondents who found that there exist positive relationship between agri- transition and market demand, 67 percent of respondent had replied that now a day's farmer basically grow that selective crop which are in high demand. Another 19 percent of respondent replied that farmer basically grow that crops which demanded on daily basis like vegetables. The 9 percent of respondents found that Jhum output is organic in nature and due to market demand for organic products the farmer continues to grow for earning and remaining 5 percent believed that orchard items and market are highly interrelated and even they exported fruits like orange, pineapple etc from their village in last year.

13. In your village any agricultural/ horticultural officer, staff etc ever visited within last 1 year? Yes/ No, if yes please specify what kind information they provided.

\begin{tabular}{|c|c|c|}
\hline Response & Yes & No \\
\hline Household & 0 & 25 \\
\hline
\end{tabular}


Interpretation: whereas, there are Agriculture, Horticulture department in District headquarter just $15 \mathrm{~km}$ in distance from village but still no any officers and staffs from both department had ever visited to impart any kind of knowledge or information. Unfortunately no supportive tools had ever provided to 25 respondents in study area.

\section{In your village is there any kind of restriction prevailing regarding the practice of shifting cultivation? Yes / No, if yes who are}

\begin{tabular}{|c|c|c|}
\hline Response & Yes & No \\
\hline Household & 0 & 25 \\
\hline
\end{tabular}

Interpretation: In the study area there is no any kind of restriction for Jhum cultivation in region.

\section{RESULT AND DISCUSSION:}

People are traditionally dependent on shifting cultivation for their food production and cash generation. The staple foods in villages are produced for both consumption and exchange. Majority of people in survey area who depend on agriculture were from low income groups, whereas high income households are more involved in business, livestock rearing etc. There is variation in production also where most of the products were consumed by producers themselves and remaining is sold. Further shifting cultivation is organic where various commercial foods and crops originated from it. Its commercial value is increasing and farmers adjust their crops selection more to commercial species for sustaining their livelihoods. Many shifting cultivator are increasingly integrated to cash crops, where the cultivators produced a group of commodities which are traded locally, regionally and enabling cultivators to provide resources which is beneficial to themselves and to the society.

Farmers are changing from subsistence to cash crop farming. Again most of the farmers due to lack of capital continued depending on traditional subsistence farming and farmers who can afford capital, plant high cash crops and the fact that a substantial portion of agricultural produce are sold in the market by a household and surplus income is merely reinvested in agriculture.

In order to figure out the relationship between Jhum cultivation and deforestation, the study of Raygorodetsky, Gleb; (2016) under Hin Lad Nai village of Thailand claimed that the practice of Jhum/shifting cultivation has been practicing for centuries. It is age-old and worldwide practice of clearing patches of forest to plant crops for a few seasons, then letting the woods return. Eventhough Hin Lad Nai forest has remained remarkably healthy, despite centuries of shifting cultivation. In study area the farmers also practicing Jhum since from centuries but in a way that forest may regrow after left the field or adopting an alternative like plantation, orchard etc.

Life and culture of the people of study area depend highly on Jhum cultivation. The hilly terrains are responsible for poor yield of agriculture. Various policies and programme implemented by Government in order to provide alternative livelihood sources to local population is unsatisfactory. Due to small market size and number of problems in Jhum cultivation and converting Jhum to settled cultivation is not an easy task until the viable livelihood options are provided to farming community.

\section{CONCLUSION:}

To conclude, in the study area the Jhumias are totally dependent on Jhum for their daily needs and cash generation. Due to rising demand for organic product and Jhum output like Oyin (Clerodendrum colebrookianum), Hubbsi (Schizophyllum commune), Heibe (Xanthoxylum), Kope (Solanum uporo), Bayom (Brinjal) etc. which are totally an organic by or in nature, the farmer are transforming from subsistence to more cash crop faming. Lack of proper market channel has led the cropper to cultivate under small plots of land where half of the output is consumed by household itself and remaining are traded to buy other necessary items for their household.

The study also concludes that deforestation and Jhum cultivation has no direct relationship in the study area. Whereas, the Jhum is traditional farming system in the region, if it would be the reason for deforestation than forest cover would have disappeared in area before current era. While commercial logging and construction were some of the major causes for deforestation in the study area. 
Finally, the output from Jhum is low in compare to permanent cultivation but there is continuity of Jhum cultivation in region due to lack of other alternative. However, there are department like Agriculture and Horticulture which are supposed to provide various programmes and policies implemented by Government is found to be unsatisfactory.

\section{REFERENCES:}

1. Burmon, A. K (1977), "Tribal Agriculture in the North-Eastern Hill Region”, Social Scientist, Vol. 6, No. 3, pp. 61-68 http://www.jstor.org/stable/3516822

2. Casero et al. (2009), "From Shifting Cultivation to Sustainable Livelihood Creation: Strengthening Marginalised Communities through Institutional Development and Microfinance for Agroforestry and Energy-efficient Technologies", Institute for Global Environmental Strategies (IGES) Forest Conservation, Livelihoods, and Rights Project 2108-11 Kamiyamaguchi, Hayama, Kanagawa 240-0115 Japan

3. Gaskins, S (2003), "From Corn to Cash: Chango and Continuity within Mayan Families", Ethos, Vol. 31, No. 2, Theme Issue: The Cultural Construction of Childhood, pp. 248-273 http://www.jstor.org/stable/3651938

4. International Mountain Society (2006), "Land Use Transition, Livelihoods, and Environmental Services in Montane Mainland Southeast Asia", Mountain Research and Development, Vol. 26, No. 3, Land Use Transition in Montane Mainland Southeast Asia (Aug., 2006), pp. 278-284 http://www.jstor.org/stable/4096464

5. Kerkhoff and Sharma (2006), "Debating Shifting Cultivation in the Eastern Himalayas Farmers' Innovations as Lessons for Policy", International Centre for Integrated Mountain Development (ICIMOD) G.P.O. Box 3226 Kathmandu, Nepal

ISBN-10 92-9115-009-6

ISBN-13 978-92-9115-009-0

6. NSSO $70^{\text {th }}$ Round (2013), "Key indicators of land and livestock holdings in India \& Key Indicators of Situation of Agricultural Households in India".
7. Patel et al, (2013), "Socio-economic and environmental changes with transition from shifting to settled cultivation in north-eastern India: an ergonomics perspective”, International Journal of Agricultural Science and Research (IJASR), ISSN 2250-0057 Vol. 3 Issue 2, Jun 2013, 117-136

8. Poffenberger, M (1983), "Changing Dry land Agriculture in Eastern Bali”, Human Ecology, Vol. 11, No. 2, pp. 123-144 http://www.jstor.org/stable/4602692

9. Singh, G. B. (1988), "Review: The Tribal Economy: Continuity or Change?", Social Scientist, Vol. 16, No. 4, Four Decades of Economic Development II , pp. 64-67 http://www.jstor.org/stable/3517260

10. Sustainable Mountain Development Summit- IV Arunachal Pradesh, Itanagar (2015), "Sustainable Land Management Practices to Help Women Farmer Address Land Degradation in Nagaland" UNDP- GEF SLEM project Nagaland, Kohima 797001, India.

11. Thrupp et al. (1997), "The Diversity and Dynamics of Shifting Cultivation: Myths, Realities, and Policy Implications", World Resources Institute. All rights reserved. ISBN 156973-230-2, Library of Congress Catalog Card No. 97-80524.

12. Wangpan, T and Tangjang, S (2012), "Slash-andburn agriculture in Eastern Himalayan zone of Arunachal Pradesh, North East India”, current science, VOL. 102, NO, 9

13. https://indikosh.com/vill/277031/kombotarsumob uk

14. http://www.census2011.co.in/data/village/263581kombo-tarsu-mobuk-arunachal-pradesh.html

15. http://news.nationalgeographic.com/2016/03/1603 03-thailand-farmers-slash-and-burn-forestsclimate-environment/

16. http://morungexpress.com/new-study-says-Jhumcultivation-not-adverse-ecology/ 